of the Society. A drawing of a hand emphasizing the features of finger-and palm-print patterns is reproduced from this article. The memorandum is, however, essentially concerned with the results of successful tests in the long-distance identification of criminals conducted during the past year by New Scotland Yard in co-operation with the Commissioner of Police, Victoria, Australia, and Messrs. Cable and Wireless, Ltd.

The report is illustrated by a specimen transmission card which contains, in addition to two photographs of the wanted person, an enlarged print of one finger with coded description of the other nine digits, and a complete description of the individual, and the information required in connexion with him. All this matter is contained on a card approximately 10 in. $\times 9$ in. in size; and this formed the picture which in one test was transmitted from London to Melbourne in seven minutes so successfully that a cable setting forth the person's record was received from Melbourne the next morning. These tests thus culminated in the successful identification in Australia of a person who was actually in custody in Great Britain and whose trial was imminent. Similar facilities for radio picture transmission are now available between London and many towns in various parts of the world, both within and outside the British Empire.

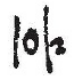

\section{BIRDS OF PALESTINE}

$\mathrm{W}$ HILE rerying in Palestine, Captain Eric Hardy became Ne secretary of the Jerusalem Naturalists Club wh ch had been founded for the troops by Middle Command to stimulate interest in and co-ordines the numerous inquiries in natural history tha $\mathrm{re}$ already being pursued by a number of inf r dual soldiers. One of the most notable activities of the Club was the listing of the birds of Palestine. The duty was undertaken because of the lack of a modern and authoritative account of Palestinian birds, and, besides their records of 364 species and 68 sub-species, work was also carried out on problems of migration. These, together with records of the most-used bird haunts, have been put together by Captain Hardy in a privately printed list which, it is hoped, will be the forerunner of an authoritative and comprehensive handbook of "Palestinian ornithology*.

The region is of particular interest because the Palæarctic region of the north and the Ethiopian region of the south meet across the centre of the country. The little owl, for example, shows interesting northern, southern and intermediate races, and several African birds like the sunbird (Cinuyris), the darter (Anhinga), the sooty falcon and the lappetfaced vulture (Otogyps) penetrate the country from the Syro-African Rift Valley, and oriental birds like the fishing owl (Ketupa) and the black-headed bunting (Emberiza melanocephala) also occur. The main migration routes between Europe and Africa pass through the country.

The only native bird to migrate to Palestine is the gannet (Sula bassana), although several 'British' species from eastern Europe, like the European swallow, the rook, redshank, teal and cuckoo, are seen. There are also several clusely allied races of

* A Handbook of the Birds of Pulestine. By Capt:xin Eric Hardy. Pn. iii +50 . (Education Othicer-in-Chief. G.H.Q., Middle East Forces, 19:6.) the birds known in Britain, like the chaffinch, great tit, kingfisher, robin, song thrush and blackbird. The blackbird, skylark and song thrush do not sing in Palestine in their winter sojourn, and the robin sings only occasionally at daybreak. The cuckoo rarely calls on its migration; nightjars do not sing. Absence of bird song, particularly thrush song, is noticeable to the British visitor, but the song-birds common to Britain and Palestine are the greenfinch, great tit, chaffinch, goldfinch, corn-bunting and, occasionally, the chiff-chaff. The familiar calls of the robin and redshank are commonly heard in winter, but the robin, as well as the blackbird and song thrush, are much shier and less easy to approach than in Britain. Birds peculiar to Palestine include the Palestine babbler, the Palestine blackstart, the Palestine graceful warbler, Tristram's grackle and the Palestine sunbird. The grackle and the sunbird are extending their way northwards from the Dead Sea depression. The bulbul is supposed to have increased its numbers considerably this century, but several birds have decreased. The white stork, the lammergeir, the imperial eagle and the white-faced duck no longer nest in the country, while the great bustard, the Syrian ostrich and the Egyptian goose are apparently extinet in Palestine. Unlike Cairo, Jerusalem and the cities of Palestine are not the habitat of flocks of kites, but also unlike Cairo, Jerusalem, Haifa and Tel Aviv have a large summer nesting population of swifts.

\section{CARNEGIE INSTITUTION OF WASHINGTON}

REFSRT FOR 1944-45 Washingtpl, Br. Vannevar Bush, which is included, togempr With the reports of the executive committee, the atoftors, and on departmental activities, in the Yeakbok No. 44 for 1944-45, covering the year July 1, 1944-June 30,1945, is that in which he discusses the future of scientific research, and particularly the bearing on it of the Selective Service, the further extension of which as regards science and engineering students has since been severely criticized by H. A. Meyerhoff (Science, April 19). Dr. Bush points out first that while the United States is at last awake to the value of scientific researeh, it is not by any means certain that every area where the scientific method can add to man's understanding of himself and his environment will be adequately explored, and that the danger of lack of balance between applied research, research in the physical sciences, medical science and in other fields may be exaggerated by the serious deficit in scientific man-power due to the policies pursued during the War. The two governing principles, that every citizen should be ready to sacrifice equally in the common cause and that every man should be used in the place where his talents can contribute most fully to the common effort, were not in balance. As a result, by taking too many trained young scientific workers and engineers out of the laboratories and industry, part of the war effort was nearly wrecked, while at the same time the future was sacrificed to immediate needs and a lack of scientific man-power created from which the country will not recover for many years. 
Dr. Bush believes that the lack of a sufficient number of brilliant young men with a basic training in fundamental science will be particularly unfortunate and will severely handicap the Carnegie Institution in the immediate post-war years. While, however, we have had a partial moratorium on the creations of fundamental science, and have caused a deficit of scientific man-power, we have undoubtedly a new stock of dammed-up ideas. This factor, together with the probability of adequate support for scientific effort, makes the vista in science attractive if we can assume a peaceful world. To ensure that the present emphasis on science does not result in unbalance and a neglect of other fields of effort, it is essential to educate fully all the young and brilliant minds that can be found and to present clearly the various callings as young men start their careers, so that none requiring recruits is overlooked, not forgetting that political careers must be made attractive for sound thinkers if democracy is to function effectively in a world of growing complexity.

The Institution, the president reports, has emerged from the War in sound financial condition, with increased endowment, although the rate of income from endowment has dropped severely. It has conducted much war research under contract for the Government, contributing its facilities, its normal overhead and the services of its regular staff, and being reimbursed only for additional staff, equipment and overhead. The salary scale of the Institution requires revision, and a new retirement and insurance plan has been put into operation.

As regards the research activities of the departments and divisions during the year, there is in general little to add to the broad picture given in the previous Yearbook (see Nature, 156, 453; 1945). Reference may, however, be made to plans of the Department of Terrestrial Magnetism for the investigation of phenomena of thunderstorms and its investigations of the rate of ionization inside a room. Some results of the attempt of the Division of Zoology of the United States Public Health Service to correlate by radioactive-tracer techniques the localization of heavy metals in the body and their chemotherapeutic activity are reported, as well as ionospheric data obtained at Watheroo and Huancayo Magnetic Observatories. The Division of Plant Biology has found that the antibiotic properties of the material isolated from cultures of the green alga Chlorella are due to, or associated with, the presence of unsaturated fatty acids, but the activity only develops on exposure to air and light. Pure unsaturated fatty acids showed the same behaviour, including linoleic, elaidic, $\beta$-eleostearic and $\beta$-licanic acids. In the Department of Embryology much time has been devoted to the perfection of a new technique of microtomy intended to reduce the distortion of tissues caused by the pressure of the microtome knife, and the position of embryology as a co-operative science is discussed in the report in relation to future work of the Department.

In the Department of Genetics cytogenetic studies reported include the induction of mutations in the short arm of chromosome 9 in maize and preliminary studies of the chromosomes of the fungus Neurospora crassa. An extensive investigation of the genetics of acquired bacterial resistance to drugs and other antibacterial agents has been initiated, including work on resistance to penicillin, sulphonamides, inorganic salts, bacteriophages and ultra-violet radiation. Other work has been directed to the develop- ment of high-yielding strains of Penicillium by submerged culture and of an aerosol method for the chemical treatment of Drosophila melanogaster, and work on the cytogenetics of Drosophila and the genetic structure of natural populations is also reviewed. The report of the Nutrition Laboratory includes a brief review of the contributions of the Laboratory during the last thirty-eight years, emphasizing the work on the development and testing of apparatus for the measurement of heat production and elimination, respiratory exchange and surface and internal body temperature.

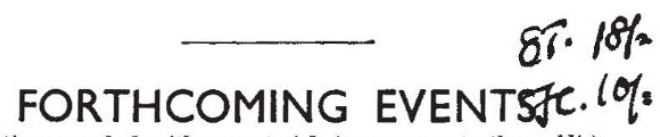

(Meetings marked with an asterisk * are open to the public)

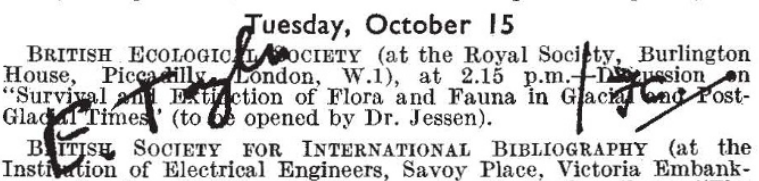
B ITISE SOCIETY For INTERNATIONAL BIBLIOGRAPHY (at the
Instivion of Electrical Engineers, Savoy Place, Victoria Embankment, London, W.C.2), at 2.30 p.m.-.Dr. B. M. Crowther: "The Use of the Universal Decimal Classification in Periodical Abstracting Services for Scientists and Engineers"; Dr. S. C. Bradford: "The Problem of Complete Documentation in Science and Technology". LoNDon School OF Economics AND Polimical SCIENCE (at
Houghton Street, Aldwych, London, W.C.2), at 4.45 p.m.-Sir Houghton Street, Aldwych, London, W.C.2), at 4.45 p.m.- - Sir
Theodore Gregory: "The Outiook for India"." (To be repeated on October 21 and 22 .)

\section{Wednesday, October 16}

INSTITUTE OF FUEL, YORKSHIRE SECTION (at the University, Leeds), at 2.30 p.m.-Dr. A. L. Roberts: "Radiant Heating-its Principles and some Applications",

Society OF Chemical Industry, Agriculture Grodp (in the Physical Chemistry Lecture Theatre, Royal College of Science, South Kensington, London, S.W.7), at 2.30 p.m.-Dr. F. Gross: "An Experiment in Farming the Sea"*. RoYal Mrcroscopical Society (in the Hasting Hall, B.M.A.
House, Tavistock Square, London, W.C.1), at 5 p.m. Mr. E. Wilfred Tavlor: "Improved Image Illumination and Co trast with the Taylor: "Improved Ima

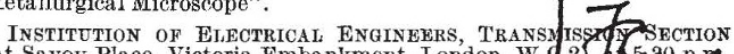
(at Savoy Place, Victoria Embankment, London, W. .2), ha30 D.m. Institute of Petrolieum (at 26 Portland Place, Iondon, W.1), at 5.30 p.m.-Mr. A. T. Wilford: "The Lubrication of Pre-Selective Gearboxes",

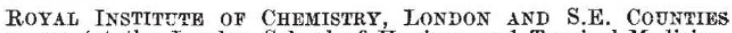
SECTION (at the London School of Hygiene and Tropical Medicine, Keppel Street, London, W.C.1), at 6.30 p.m.-Discussion on "The Publicity of Science by Radio" (to be opened by Dr. W. E. van Heyningen)

ROYal Institute OF Chemistry, NeWCASTle-UPON-TyNe AND NORTH-EAST COAST SECTION (joint meeting with the SOCIETY OF CHEMICAI INDUSTRY, in the Chemistry Lecture 'Theatre, King's College, Newcastle-upon-Tyne), at 6.30 p.m.--Lieut.-Colonel A. Wedgwood :

BRITISH Association of Chemists, LONDON slectov (at Gas Industry House, 1 Grosvenor Place, London, S.W.1) at 7 F.M.- Mr. J. H. F. Smith: "Fire and Explosion: 1 . Inflammab e Cousentpations
and Ignition Temperatures".

\section{Thursday, October 17}

Chemical Sochety (joint meetings with the Sovth YoRkshirk SECTION OF THE ROYAL INSTITUTE OF CHEMISTRY, the SHEFFIELD METALLURGICAL ASSOCIATION, and the SHEFFIELD UNIVERSITY CHEMICAL SOCIETY, in the General Lecture Theatre, The University, Western Bank, Sheffield), at 2.30 p.m. and 6 p.m.-Prof. Jaroslay Heyrovsky: "The Principles and Applications of Polarography".

Institute of Fuel, EAst Midland Section (at the Gas Demonstration Theatre, Nottingham), at 3 p.m.-Babcock and Wilcox Film "Steam" (presented by Mr. E. L. Luly).

Instimution of Mining AND METAludrgy (at the Geological Society, Burlington House, Piccadilly, London, W.1), at 5 p.m.Major P. L. Teed : "Anglo-American Magnesiur Production"; Dr. Anthony Caplan and Mr. J. K. Lindsay : "An Experimenr 1 . Investigation of the Effects of High Temperatures on the Hfficiencf of W w rkers
in Deep Mines".

Institution of Electrical ENGINEERs, Insqallations SECTION (at Savoy Place, Victoria Embankment, London, W.C.2), at 5.30 p.m. -Mr. J. F. Shipley : Inaugural address as Chair fan.

SOCIETY OF Chemical INDUSTRY, ROAD AND BUILDING Materials GROUP (joint meeting with the RHEOLOGISTS' CLUB, at Gas Industry Group (joint meeting with the RHEOLOGISTS' CLUB, at Gas Industry
House, 1 Grosvenor Place, London, S.W.1), at 6 p.m-Dr. G. W. ScottHouse, 1 Grosvenor Place, London, S.W.1), at 6 p.m-Dr. G. W. ScottMaterials". 